\title{
Comparing Two Translations of Abdel-Tawab Youssef's A Biography of Prophet Mohammad Peace Be upon Him in Twenty Stories: A Skopos Functional Approach
}

\author{
Rania Abdel Baky Allam \\ Lecturer, Faculty of Languages, MSA University, Egypt.
}

\begin{abstract}
The present paper is a comparative study probing the two translations of Abdel- Tawab Youssef's (2008) book حياة محد صلى اله the first by Calderbank in (2010) and the second by Enani in (2017a), using Nord's (2005, 2018) text analysis, looping model. The source text (ST) is intended for young readers, as a biography of the Prophet related by animals and objects. It has referential, expressive and appellative functions exhibiting literary ingenuity. Applying Nord's functional extratextual and intratextual factors proves that the two translators adopt dissimilar translational strategies, resulting in variant target texts (TTS) with divergent skopoi. Calderbank adopts a documentary, literal type of translation creating a market-oriented text, greatly echoing the ST with rather simple diction and mostly paratactic constructions, targeting mainly young children, however with less originality and amusement. Enani adopts an instrumental, well schemed type of translation resulting in an ingenious target language-oriented text, with rather elevated diction and mostly hypotactic constructions, targeting mainly elder, more mature readers with notable resourcefulness and inventiveness. Thus, Calderbank's TT skopos is empowering the hit of an amusing
\end{abstract}

\section{ELLS VoI.9 No.I (325) SPU December 2018}


Comparing Two Translations of Abdel-Tawab Youssef's A Biography of Prophet Mohammad Peace Be upon Him in Twenty Stories :A Skopos Functional Approach children best seller, while Enani's TT skopos is creating a mediating channel between the TR and the SC, in cross cultural translational communicative action.

Keywords: skopos, translation-orientated source text analysis, extratextual and intratextual factors, translation brief, documentary and instrumental translation. 


\section{Comparing Two Translations of} Abdel-Tawab Youssef's

A Biography of Prophet Mohammad Peace Be upon Him in Twenty Stories: A Skopos Functional Approach Rania Abdel Baky Allam

Lecturer, Faculty of Languages, MSA University, Egypt.

\section{Introduction}

Translation as a tool of bridging the gap between cultures can come in varied forms for the same source. The present paper is a comparative study probing the two translations of Youssef's (2008) book حياة محد صلى الله عليه و سلم فى عشرين قصنة as a source text (ST). The first one is translated by Calderbank as The Life of Prophet Muhammad Peace be upon him in Twenty Stories (2010) and the second by Enani as The Life of the Prophet in Twenty Tales (2017a).

The comparison between those two target texts (TTs) is drawn within the framework of the functional skopos theory and Nord's $(2005,2018)$ looping model of translation. In such model, Nord asserts the idea that the purpose or skopos (a Greek word) of the TT is the main pivot on which the whole translational process is based. The translator should produce a TT with a target-audience oriented skopos achieving a certain communicative function in a certain target situation (TS) bound to the target culture (TC) and mainly determined by its receiver. Such purpose is achieved through determining the skopos of the TT first, then analyzing the components of the ST, its subject matter, the intention of its author as well as its final purpose and function in respect to the ST receivers. Therefore, the translator would be able to determine his translational strategies and decisions prior to the translation act.

\section{ELLS VoI.9 No.I (327) SPU December 2018}


Comparing Two Translations of Abdel-Tawab Youssef's A Biography of Prophet

Mohammad Peace Be upon Him in Twenty Stories :A Skopos Functional Approach

\section{Theoretical Background}

\subsection{Skopos Theory of Translation and Nord Translational Approach}

Reiß and Vermeer (2014) explain the basis of the skopos theory which has developed in the 1970, upon which Nord later bases her translational approach. The theory is target based oriented. It regards any ST as being a translational action carried out with a skopos which means purpose or aim, determined by internal and external factors, and in turn determines the way by which such ST is translated. They call such translational action 'translatum'; a functional manifestation of its skopos. It is to be viewed "as an information offer for a target language and culture (IOT) about an information offer from a source language and culture (IOS)" (p.69).

Following the same purposeful approach, Nord adopts the notion of the skopos functionalists that translation is "an activity geared toward a communicative aim or purpose" (Nord, 2006a, p. 133). If the TT is to function in a certain TC situation for which it is produced, it "should be provided with the necessary markers to indicate the intended functions to the target recipients" (Nord, 1995, p. 262). Hence, it is the translator's task to decide on such markers to render the TT functional for the target recipient (TR).

Accordingly, the translator as a cultural mediator between the source culture (SC) and TC needs to be aware of certain elements which help analyse the purpose of the ST and the intention of its author. This is what Nord calls "translational intention" which has to be either similar to or at least congruent with "the intention guiding the original sender or text producer in the production of the source text" (Nord, 1997a, p. 45).That is why; Kalliomäki (2007) asserts that "although the translator is nowadays allowed to be more visible than before, the readers still expect the translations to follow quite strictly the source text. The translator has to consider these expectations, but s/he is not bound to them" (p. 8).

\section{ELLS Vol.9 No.I (328) SPU December 2018}


Eschewing the idea of blind adherence to the ST and its linguistic content does not shun the idea of conformity between the TT function and that of the ST; the principle of loyalty. It is the interpersonal concept referring to relationship between persons (the ST authors, senders, receivers).Such concept is supposed to govern the translation process by ethical reliability. "Loyalty may replace the traditional intertextual relationship of 'fidelity', a concept that usually refers to a linguistic or stylistic similarity between the source and the target texts, regardless of the communicative intentions and/or expectations involved" (Nord, 2006b, p. 33). Accordingly, the translator has to respect the sender's communicative intentions, taking various translational culturespecific concepts into consideration (Nord, 2016, p. 571).

Functionality and loyalty principles entail extensive steps of analysis of the ST internal and external factors or details to achieve adequacy with respect to the TT skopos. Ramos (2002) thinks that "the overall goal of adequacy may thus justify the use of a variety of strategies in different translation situations" (pp. 28-29). The factors or details which guide the translational strategies are stated in what Nord (2018) calls "translation brief" (TB) or commission to be provided by the "translation initiator" (TI) or commissioner who initiates the activity of translation in the first place (p. 20). The TB contains information about the intended skopos through determining, text function(s), the TT addressee(s), the time and place TT release, the medium of transmission and the TT motive (Nord, 2008, p. 57).

\subsection{The Looping Model or Translation-Oriented Text Analysis}

Nord's translation-orientated source text analysis (TOSTA) model of translation can be actualized in the analysis of the TT skopos, identified by the TB, the analysis of the ST; its gist, significant elements, situation, cultural milieu, the accentuation of translation-relevant ST cultural, communicative elements, their adaptation, to the TT skopos and their matching with the corresponding target language (TL) cultural, communicative

\section{ELLS Vol.9 No.I (329) SPU December 2018}


Comparing Two Translations of Abdel-Tawab Youssef's A Biography of Prophet

Mohammad Peace Be upon Him in Twenty Stories :A Skopos Functional Approach

elements, through applying a certain translation strategy, the final synthesis is structuring of the TT with its predetermined functionality or skopos (Nord, 2005, pp. 36-39). The following diagram explains the whole process.

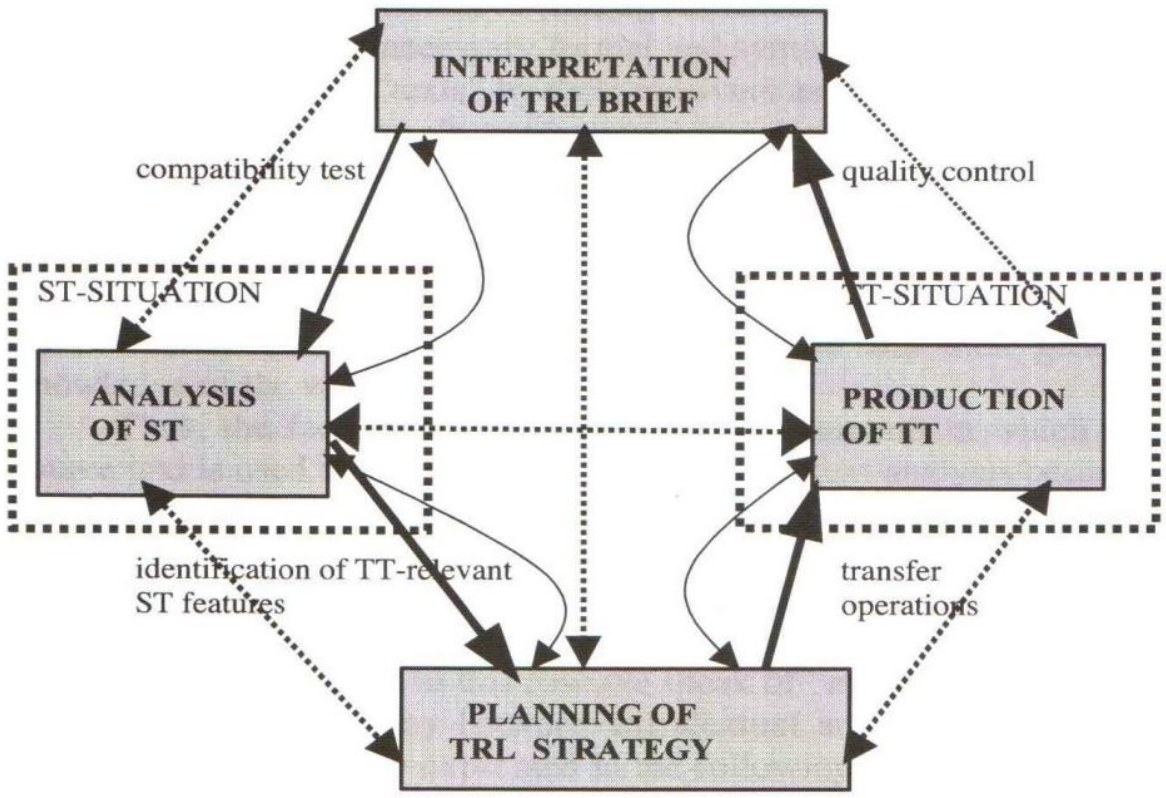

(Nord, 2008, p.39).

Sas (2010) postulates that this model does not impose a replacement of ST elements with TT counterparts, thus the standpoint is changed not 'bottom-up' as in the linguistic model, but a 'top-down', the skopos is the starting point. Hence, a single ST can have as many TTs as possible according to the TR expectations and needs.

\subsubsection{Extratextual and Intratextual Elements}

The extratextual and intratextual ST factors have a great impact on the translational actions taken by the translator. They are scrutinized by using what Nord calls "New Rhetoric formula" explained and expressed in a series of wh-questions. The first set of questions enquires about the extratextual features: who sends to

\section{ELLS Vol.9 No.I (330) SPU December 2018}


whom, what for, through which medium, where and when, why and with what function. The second set of questions enquires about the intratextual features, what is the ST subject-matter, what the ST says, what is not presupposed, in what order, with which non-verbal elements, in which lexical content, in what kind of syntactic structure, by what suprasegmental features and finally to what effect on the TR, (Nord, 2005, pp. 41-139).

\subsection{Text-Functions in Translation}

In the present study, the $\mathrm{TB}$ is not readily accessible or available. Therefore, the translation function and skopos for each TT under study are to be deduced by the researcher. Calvo (2018) affirms that "whenever the brief is not obvious, translators can deduce the purpose of the translation for themselves (implicit or tacit skopos)" (p. 21), relying on their knowledge of previous translational situations.

The functions of texts as asserted by Nord (1997b) are mainly phatic function (establishing a channel of communication between sender and receiver through sociocultural relationships), referential function (referring to objects and phenomena of the world or of a particular world), expressive function (expressing the sender's personal, attitude, feelings and outlook towards objects and phenomena expressed in the world of the text) and appellative function (persuading or inducing the receiver's to act, feel, think or respond in a particular way). Actualizing the ST above mentioned functions in the TT even if not in the exact schema is the pivot upon which the skopos theory hinges. However, the way of actualization of such functions can result in different types of translation.

Nord (2018) has a binary of her own namely; documentary and instrumental translation. Documentary translation presents a TT as a meta text that gives an idea about a certain SC text producing a rather "interlineal word-for-word translation" exhibiting "a text about a text, or about one or more particular aspects of a text" ( $p$. 46). Instrumental translation presents an autonomous TT whose "readers are not supposed to be aware they are reading a translation

ELLS Vol.9 No.I (331) SPU December 2018 
at all. The form of the text is thus usually adapted to target-culture norms and conventions of text type, genre, register, and tenor" (Nord, 2008, p. 50). In addition, Nord (2006a) thinks that, the type of translation is predetermined in the light of the function intended from the TT and which is set up in the TB. Is it translated to inform the recipient about the function of the ST in the SC, or is it translated to act as an entity of its own? (p. 142).In the present paper, it is expected that the two produced TTs would have two variant skopoi, and thus would exhibit key differences of diverse linguistic rendering.

\section{Previous Studies}

A lot of studies deal with skopos theory as well as Nord's looping model of text analysis. Among such studies is the one conducted by Hanninen (2006) who uses Nord's model of text analysis in the studying the translation of magazines. The study proves that the tools of extra and intra textual elements are quite very functional in the analysis of the detailed elements of translated magazines.

Sas (2010) conducts a study investigating the procedures of translating children's literature from Dutch into English. Using Nord functional, translational approach, the researcher examines the cultural discrepancy as well as the reluctance of the English speaking children to receive foreign literature. Such functional approach has proved that the translated work is domesticated and adapted to a British cultural background.

Moreover, Alsabbagh (2014) conducts an M.A. thesis using skopos theory in analyzing the translation of children's literature; namely an Arabic version of a passage from the novel The Wind in the Willows. The research exhibits the idea that, children literature poses more translational challenges than adult literature. The study also proves that skopos theory provides effectual, accessible strategies of analyzing such challenges and difficulties in the translation of this kind of literature.

\section{ELLS Vol.9 No.I (332) SPU December 2018}


Besides, Bouziane (2016) conducts a study on 40 online English advertisements and their Arabic versions using skopos theory so as to identify the type of functional equivalence followed in such kind of purposeful translation. The research exposes that skopos theory proves quite valid in the analysis of both textual and visual elements of target advertisements and in revealing different cultural concepts as well.

However, the most pertinent study to the present paper is a study conducted by Khalifa (2017). Her study is a reading in the two translations of Youssef's book (2008) حياة محد صلى اله علبه و سلم فح (20) and the two translations by Calderbank (2010) and Enani (2017a), employing Coillie's (2006) model, with a cultural perspective. It is based upon four factors; the translator's frame of reference, his notions of adequate translation, the influence of the actors in the literary field and the broader literary climate. Her study concludes that, both translators by adopting their own ideologies well achieved their intentions. Calderbank from her point of view balances between foreignization and domestication, and in spite of being affected by the publisher's influence, produces an enjoyable, pleasant TT. On the contrary, Enani targets curious adults as he expects that due to the misconception propagated in the west about Islam, parents would not chose such a book for younger readers. He employs domesticating strategies to make his audience familiar with the ST cultural elements, and to imitate Youssef's elevated Arabic style.

The present paper, in spite of relying on many of the results highlighted by Khalifa's study, tackles the comparison functionally with a skopos perspective based on Nord's TOSTA model (2005, 2018) rather than the linguistic and organizational model proposed by Collie. It is quite probable that the results may be close to each other. The paper gauges the extra and intra textual factors affecting both the ST and the TTs, and to what extent both TTs achieve loyalty and adequacy principles. Furthermore, the main rationale is to prove that the skopoi of the two translated texts can be inferred

\section{ELLS VoI.9 No.I (333) SPU December 2018}


Comparing Two Translations of Abdel-Tawab Youssef's A Biography of Prophet

Mohammad Peace Be upon Him in Twenty Stories :A Skopos Functional Approach

through analyzing the factors affecting both. Implications about the translation strategies adopted by each translator can help deduce the final skopos of each TT. The paper also proposes an assumption that even if no explicit translation commission is provided, the skopos of the TT can be verified in the actual translated product.

\section{Objective of Study}

The main objective of this paper is to identify the intention, typology, function and purpose of the ST on the one hand, while probing the same textual elements in each TT on the other. Pining down the extra and intra textual elements in the ST and both TTs can give an idea about the type of translation adopted by each translator (whether documentary or instrumental).

Moreover, the paper endeavors to exhibit the validity of the parameters proposed by Nord $(2005,2018)$ to be used as translational comparative tools to presume the communicative functions assigned by each translator to his TT even if the ST has literary, aesthetic, religious and cultural hues. The research thus aims to pinpoint the aptness of the translational strategies opted for by each translator to fulfill his predetermined, communicative skopos.

\section{Research Questions}

This study attempts to answer the following questions:

1. What are the main intention, communicative function and final purpose of the ST as adopted by its original author within the SC?

2. What are the translational strategies adopted by each translator to attain his TT predetermined communicative function and skopos, and to what extent they prove to be valid in each TT?

3. To what extent is it possible to construe the predetermined communicative functions and skopoi of the two TTs through analytically comparing their textual elements to those of the original ST, without being provided by the actual TB?

\section{ELLS Vol.9 No.I (334) SPU December 2018}


Rania Abdel Baky Allam

4. What type of translation is adopted by each translator according to Nord's $(2005,2018)$ terms, and to what function?

5. To what extent are the functions and skopoi of the two TTs are similar or congruent to those of the ST on the one hand, and to what extent are they similar or close to each other on the other?

\section{Methodology}

The methodology followed in this study is a qualitative one. A parallel analysis for the two TTs under study is conducted against the original ST to deduce the effect of each TT and on its TRs. First, extratextual factors affecting the ST are analyzed and compared to those affecting both TTs. Then selected examples of the intratextual factors of the ST are scrutinized and concurrently compared to their equivalent factors in the two TTs. Hence, a two-level comparison of loyalty and adequacy is conducted. The ST sender's intention and skopos are compared to those of the senders of the two TTs to gauge loyalty. Then a comparison between the two TTs' translational decisions and strategies conveying both senders' intentions and skopoi is subsequently drawn to gauge adequacy.

\section{Analysis}

\subsection{Analysis of Source Text Extratextual Factors}

The sender in the present study is the ST author Abd-ElTawab Youssef (1928-2015). He "singled himself out as one of the three musketeers of the controversial children's literature next to Kamel Kilany (1897-1959), and Mohamed Said El-Eryan (19051964)" (Sami, 2015, p. 132).Being a devoted writer for children, Youssef's intention is explicitly indicated in the preface story in his book "I am a book"; asserting that he presents a resourceful narrative capsule about the life of Prophet Muhammad peace be upon him (PBUH), compiled and based on the Quran, Hadith and Sunna heritage books, however, lacking no ingenuity or originality.

\section{ELLS VoI.9 No.I (335) SPU December 2018}


The book is based on genuine, realistic events that took place in the Prophet's life, and is meant to inform, guide, steer and instruct mainly young Arabic speaking Muslims, as stated by the author, "the juvenile, pure, young; who are beloved by God and His glorified Prophet" (Youssef, 2008, p. 2) (my translation). Its stories, being narrated, by animals, plants and objects which are parts of the related events, are not void of inventiveness, creativity and entertainment. Thus, being a devout Muslim and an enlightening writer with a mission, Youssef's motive is didactic yet pleasurable and imagination-nourishing.

The Arabic edition of the book under study is the fourth one, as the book has been a best seller for several years mounting to more than 7 million copies. The present edition is gaudily colored, in a high quality paperback, illustrated by the paintings and graphics of the celebrated artist Salah Bissar, printed in black large font letters. Such a flamboyant, visually attractive means of written transmission affirms the glitzy, ostentatious milieu of children books conforming to the ST genre. Additionally, the book, being a best seller and a winner of Suzan Mubarak's award in 1999, is reprinted by Dar El-Shorouk winning the Bologna Book fair New Horizons Publishing Award in 2000. Such celebrated atmosphere may have been the motive behind the selection of such text by the publisher, and also guarantees a well acknowledged reception by the intended SR.

As can be inferred from the authorial preface, the ST fulfills many functions. The text has a phatic function establishing a channel of communication between the author and the readers by direct vocatives calling them his dearest readers. It displays a referential function referring to objects, characters and events in the Prophet's life. It also has an expressive function as the author frequently and explicitly expresses his personal feelings and outlooks towards both the characters and events and above all towards the figure of the Prophet PBUH himself. Although the ST

\section{ELLS Vol.9 No.I (336) SPU December 2018}


does not exhibit direct appellative function; yet it attempts to incite its recipients to feel, act and behave in a manner that takes the Prophet as an example to emulate.

\subsection{Analysis of the Two Target Texts Extratextual Factors}

The sender for the first TT is Tony Calderbank, a significant translator of the Arabic Literature into English. The sender of the second TT is Mohamed Enani a prominent professor of literature and translation, a leading playwright and an eminent scholar. The two TTs' senders are quite distinguished figures in the translation field. The intentions and motives of the two TTs' senders are apparent in the blurb written by each. Calderbank is most probably assigned by Dar El Shorouk to translate its Bologna Book fair award-winning book or maybe self-driven to translate such a highly celebrated best seller. However, it is much likely that the translation commissioner is the publisher Dar El Shorouk, as Calderbank's blurb is more or less a translation of the one written by Ibrahim El Moa'lem the chairman and founder of Dar El Shorouk, except for a few added segments about the stories time span. He is also keen to give credit to the publishing house, the Bologna Book fair award and the illustrations by Bissar. Calderbank's intention is rather narrative, informative and entertaining, giving no shades of expressive opinions of glorification or exaltation overtly conveyed

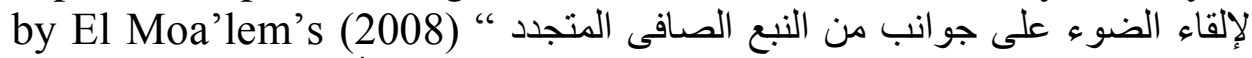
"لسيرة الرسول الكريم الذى أرسله الله رحمة العالمين (blurb). Consequently, it can be presumed that, Calderbank's translation strategy displays the fantastical hues of a children literary biography. Therefore, little heed for literary dexterity or profound rendering of aesthetic values is expected in his final TT.

Enani is most probably self-driven to translate such a biography of the Prophet, written by a writer whom he considers "the master of children's literature par excellence" (Enani, 2017b, p. 29). His motivated intention is rather apparent in his blurb, being a

\section{ELLS Vol.9 No.I (337) SPU December 2018}


renowned playwright and scholar; he finds an esteemed stupendous piece of art worthy of transference to other TC.

The intended TRs from the two translators' point of views can also be detected from their blurbs. Calderbank states clearly that the book "is written especially for children and young readers" (Calderbank, 2010, blurb). Accordingly, he identifies the recipients of his TT to be children and young readers who may or may not belong to different TL, religion and TC. On the other hand, Enani broadens the sphere of his potential TRs to encompass along with "young Muslim readers", "older audiences, regardless of the religious creed" (Enani, 2017b, p. 31). Enani's translation strategy is based on exhibiting to a wide range of readers the literary eminence, the thorough exposé of lucid narration, the meticulous presentation of the Prophet's biography. Therefore, an insightful exhibition of rhetorical aptitude and a deliberate display of linguistic propensity is expected from his TT.

Calderbank's TT medium of production is the English mirror of Dar El Shorouk's Arabic edition. Print format, type of paper, cover, colours, illustrations and layout are the same with only the verbal content being English. Accordingly, the TT synthesis is supposed to echo the childish vivid, glowing style, to be directed to young English speaking TRs. While Enani's TT medium is different from both the ST's and Calderbank's. Enani's TT is published first online then later in a volume written for a certain purpose explicitly exhibited in its title For the Love of Abdel- Tawab Youssef (2017a). Published as a part of an academic release, it is printed in black and white, small font, serious format with no colours or illustrations.

\subsection{Analysis of the TTs Intratextual Factors}

The ST subject matter is a religious biography related as fables. Thus it falls under the norms of both religious and children literature. Serban (2006) believes that texts with characters, figures, events and verses "have traditionally embodied core values of particular cultures, influencing the beliefs and behavior of large

\section{ELLS Vol.9 No.I (338) SPU December 2018}


numbers of people" (p. 47). Therefore, translating them is critical involving precision and sensitivity. Besides, "the author is understood not to be free to create the world that animates the subject matter, but to be merely instrumental in exploring it" (Dickins, Hervey, and Higgins, 2002, p. 178). To what extent and how both translators are instrumental in depicting such a world is the pivot of the present study.

The ST also belongs to what can be termed juvenile or children literature. Alsabbagh (2014) provides a rather broad definition for children literature. It is "anything that children read, not just picture books" (p. 9), even if it is written in a relatively advanced language. The ST under study works on two levels. It is an exciting group of fables as well as an engaging rendering of universally pertinent life experiences. Hence, it is eligible for both children and adults.

The two translators convey the core message of the ST subject matter. Nonetheless, the conventions and stipulations of the ST genre and subject matter with various literary and cultural hues are rendered quite singularly by the two translators, as both have different cultural and religious background and different translational intentions as well. Al Khamiri (2015) thinks that "the more translators know about the source culture, the more they will be able to transfer the ST context and content faithfully" (p. 24). Thus, it can be presumed that the one who is more familiar with the Arabic and Islamic culture would offer the TR close experience to that of the SR within the same SC context. Such hypothesis would either be proved or refuted through the analysis of the lexical, syntactic and suprasegmental fabric of the intratextual features of the two TTs.

\subsubsection{Lexical Features}

Each translator employs certain lexical items according to his predetermined target skopos, and to the function he assigns to his كانت حليمة فقيرة مسكينة، تعيش : text. This can be detected in the following : هى و زوجها "الحارث" فى خيمة، فى منطقة قليلة المطر، قليلة الخضرة، قليلة الخير

\section{ELLS Vol.9 No.I (339) SPU December 2018}


Comparing Two Translations of Abdel-Tawab Youssef's A Biography of Prophet

Mohammad Peace Be upon Him in Twenty Stories :A Skopos Functional Approach

Haleema was a poor woman who struggled hard to make ends meet. She lived with her husband "Al Harith", in a tent in a region where there was very little rain and very little vegetation Calderbank (C)/ Haleema was a poor, even destitute. She lived with her husband Al Harith, in a tent, in a region where rain was scarce, with scant verdure and meagre resources Enani (E).

The usage of elevated, literal, rather formal lexis is more prominent in Enani's TT. The adjectival group "مسكينة" is idiomatically rendered in Calderbank's TT "struggled hard to make ends meet", while substituted by a rather formal adjectival group "destitute" in Enani’s TT. The ST parallel segments "قليلة المطر، قليلة "الخضرة، قليلة الخير straight forward diction, deleting the third segment by Calderbank. Enani renders them aesthetically and pragmatically with rather complex, literary diction. This can also be detected in the following

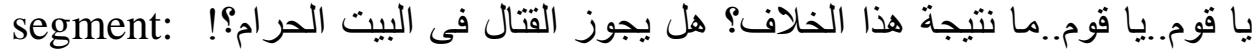
averyone, everyone! What is the result of your arguing? Is it allowed for us to fight in the Holy House? Bring reason to your mind and cast out Satan from amongst you $(\mathrm{C}) /$ Listen to me! What can this dispute lead to? Is it allowed to start a fight at the inviolate Sherine? Let your reason prevail, banish the devil forthwith! (E)

The usage of lexical items in the two TTs is apparently diverse. The vocative at the beginning of the ST segment " يا قوم...يا "قوم is so much foreignzed in Calderbank's TT, using a rather peculiar vocative "everyone". While on the contrary, Enani produces a familiar TT segment employing the imperative clause with no vocative "Listen to me". Besides, the two successive interrogatives are quite literally handled by Calderbank, employing a rather word-for-word strategy. Enani's two interrogatives are TL oriented, as the verbal group "prevail" is frequently used with the nominal group "reason". Besides, the usage of the nominal "devil" in the context of evil is more pertinent than "Satan", which is

\section{ELLS Vol.9 No.I (340) SPU December 2018}


employed in religious, liturgical contexts and scripts. Enani, in addition bears in mind the religious subject matter of the ST, therefore, he employs some archeological lexical items to keep the religious, rather historical spirit of the ST. This is apparent in his segment, in the imperative infinite verbal group and relatively archaic adverbial complement "banish" and "forthwith". This is also apparent in other instances of religious segments, where in addition to the usage of archaic diction a phonological musical hue is added like in the repetitive clause: أريد وجكأ... أريد وجها: I seek thy face! I seek thy face. (E). While Calderbank opts for translating it in a plain everyday diction and in the exclamative mood "How I desire to know you".

In the following segment, Enani's background as an ardent

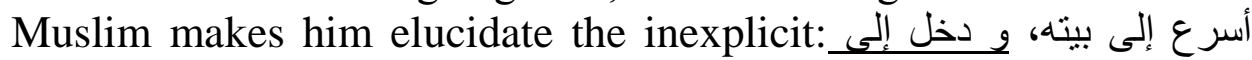
زوجته خديجة، و كان يرتعش و على جبينه حبات عرق: He hurried home and went straight to his wife Khadeeja. He was shivering, and there were drops of sweat on his forehead (C)/ He rushed back home, seeking solace from wife Khadija. As he was trembled and perished profusely. (E)

He expounds the avid, genuine relationship binding the Prophet with his wife Khadija. He also pinpoints the venerated status of women in the Islamic culture (contrary to some pervasive wrong notions about the oppression of women by Islam). Enani decides on adding a cause phrase in which the Prophet seeks succour and consolation in his wife's arms. His shivering, quavering status is literarily transferred by Calderbank who is keen even to state the details of the drops on the Prophet's forehead. Appositely, Enani expressed the same physical and mental anxiety by two verbal groups attributed by an amplifying adverbial group "profusely", which even conveys a more intensifying semantic load than that of Calderbank.

In the following instance, the two translators attempt to convey the avid keenness of the tribes to gain the honour of carrying the holy stone: واخذت كل قبيلة تجزز السيوف حتى لا يفو تها شرف حملي: Each

\section{ELLS Vol.9 No.I (341) SPU December 2018}


tribe started to make ready their swords and prepare for the battle so that they might win the chance of carrying me $(\mathrm{C}) /$ Each tribe in fact got their weapons ready. None could accept the disgrace of missing the honour of carrying me $(\mathrm{E})$.

Calderbank chooses to abide by the ST syntactic and lexical fabric of transferring the cause phrase in the affirmative form. On the contrary, Enani decides to intensify the meaning by explicating the tribal, cultural zeal that may have caused a war. He clarifies the meaning by the opposite, juxtaposed semantic load of the ST "the disgrace of missing the honour of carrying me", as avoiding disgrace is more pressing than gaining an honour.

Lexical items of different levels of formality and complexity in the two TTs can be detected throughout as follows: سيد قريش و زعيمها: Lord and Leader of the Quraysh tribe(C)/ The chief of Quraysh and eminent potentate(E), شعرنا بالخوف: felt afraid(C) /was left alone in trepidation(E),شيخًا عاقلا حكيما:a wise man(C)/ old erudite sage(E), يدفع عنها شر: الصحر اء protecting them from the dangers of the desert(C)/ fending off the ravages of the $\operatorname{desert(E)~شر~أ~مستطيراً~great~}$ harm(C)/ diabolic vengeance(E). It is also notable that in some translational segments, Enani resorts to idiomatic rendering rather than direct, non-rhetorical and literal transference frequently employed by Calderbank like in: بل زاد خوفه و اضطرابه: He just become more afraid and confused (C)/ He was at his wit's end with terror (E),إن الكفار لن يستطيعوا التغلب عليه:The Kuffar would not be able to defeat him (C)/ The unbelievers would never be able to get the better of him (E), ودهثت أنا لما حدث:I myself was astonished at what happened (C)/ And, Lo and behold! (E),و أعرف أنكم تقولون: أعوذ بالله: I know what you are saying. You are saying: "Allah protect us!"'(C)/ Snake indeed, I am, though the mere name may put you off! (E) :أبشروا...إن النصر للمؤمنين Rejoice. Victory is with the believers(C)/ Glad tidings! Victory is ours! (E):انتصر كل منهما كما انتصر حمزة / and each of them defeated his opponent (C)/ had the better of their

\section{ELLS Vol.9 No.I (342) SPU December 2018}


challenges (E). This strategy highlights the literary poise of the ST and refines the produced TT.

Supposedly, being of Arabic and Islamic background, Enani might be more aware of the ST peculiarities than Calderbank. The latter is keen not to violate any of the Arabic and Islamic cultural or religious norms. He frequently uses the pray "May the blessing and peace of God be upon him" subsequent to the Prophet's name. He opts for not translating the verses of the Quran himself, but quotes them from two established translated versions he alluded to them at the second cover page. This is in contrast to Enani who feels no urge to prove his affiliation to the Islamic norms by referring to the Prophet's name without the prayer. Besides, being an eminent translation professor and a connoisseur scholar, Enani proficiently translates the Quranic verses himself in an eloquent, articulate manner following the norms of translating old religious scripts and Bible extracts in the TL.

As clarified above, different levels of ST awareness result in inaccuracy of interpreting some Arabic and Islamic cultural and religious allusions by Calderbank. They are either dimly translated or deleted whatsoever; perhaps he thinks they would be incomprehensible for his English TR, in contrast to the rather precise rendering of Enani, like in: هذا صاحبكم قد جاء : Your Master has arrived, Your Master has arrived (C)/ There he is! The man you're waiting for $(\mathrm{E})$.

Calderbank substitutes the word "صاحبكم"which has in the source language a positive connotation of closeness, intimacy and tenderness by another nominal group "Master" which has hues of hegemony, dominance and authority not intended by the ST sender. While Enani employs a more generalized word "man", yet gives the air of waiting an anticipated welcome comer, by the phrase "There he is". Also, in the example: واحشرنى فى زمرة المساكين : Keep me always in the company of the poor (C)/ Rise on the last day among the poor! (E)The ST segment is rather a prayer by the Prophet to God to keep him in the company of the poor in the hereafter, as a

\section{ELLS VoI.9 No.I (343) SPU December 2018}


kind of reverence for such category. Thus is well articulated by Enani, whose religious and cultural background serves him well, in such instances. He elucidates the unsaid by even adding lexical items to the verbal group "rise" and the adverbial complement "on the last day" to expatiate that the author intends the afterlife. Calderbank cursorily transfers it as keeping company with no reference to the eternal world.

Besides, in this example: الذين انتهزوا فرصة وفاة الرسول و ارتدوا عن الإسلام: There were some who took the opportunity of the Prophet's death to attack Islam. (C)/ Other difficulties came about, too and had to be dealt with, urgently: some people recanted (E), Calderbank translates the idea of shunning a religion after adopting it "recanting" as "attacking" which is quite both inaccurate and erroneous. While Enani uses a more expressive TT equivalent to the ST sender's intention- the finite verb "recanted". He even adds another level of emergency of killing the destructive thoughts at the outset especially after the death of the prophet, by adding a clause ends by an adverbial attributive "urgently" to signal imminent perils.

The following group of lexical items is translated in variant ways in the two TTs. However, they all exhibit either inaccuracy or complete erroneousness in Calderbank's TT like: رجل مبروك : A holy man (C)/ A man with blessed hands(E) (as the context was relating the tale of the blessed goat milked by the Prophet),الثام: Syria (C)/ The Levant (E), العلق: clot (C)/ clot of congealed blood (E) The Jahiliyya (Era of ignorance) (C)/ pre-Islamic times (E) (Calderbank's rendering misses the timing level and Enani's misses the idea of obliviousness before Islam), سيدنا إيراهيم الخليل:Ibrahim, the intimate friend of God (C) / Ibrahim Al-Khalil (Abraham) (E) (Calderbank's rendering is not consistent with the Islamic way of thinking, which exalts God above all existence, and Enani's rendering is rather informative in a manner comprehendible

\section{ELLS Vol.9 No.I (344) SPU December 2018}




\section{Rania Abdel Baky Allam}

to the TR as he puts the English equivalent name in brackets to be pinned by the TC readers).

It can be noted also that, the metaphorical rendering for the ST segments are variant in both TTs like in: كان رجلا وديعا : He was a sweet and tender child, and beautiful like the full moon $(\mathrm{C}) / \mathrm{He}$ was a sweet, quiet and beautiful baby (E). This segment is metaphorically rendered by Calderbank following the ST structure. However, the simile is unfamiliar to the TC reader. It is even negatively signified in the TL. The full moon in western culture is associated with unpleasant transformation and evil enticement. Consequently, that is probably the reason that Enani translates it in a plain interpretive language.

Moreover, in the tale "I am a camel" the ST verb "تنشهد": و لسوف تشهد قريش موقعة جديدة: The Quraysh tribe will witness a new battle (C)/ Quraysh will feast their eyes on a new battle (E), is metaphorically dealt with by Enani to incise the meaning of trying to entrap Muhammed in a fun-ridicule ploy by confronting him with his staunch enemy Abou Jahel. Likewise in the example: يما أروعه :يومأ، و ما أعظم ذكر اه! It was indeed a wonderful unforgettable day (C)/ What an awesome day, and how powerful its echoes ringing in my memory (E), Enani resorts to the rhetorical language with aesthetic, musical hues to echo the high literary ingenuity of the ST.

The literary, oratorical originality of the ST is ricocheted in Enani's TT by employing hyperbolic, exaggerated tone which goes along with the imaginary fable-like tackling of the Prophet biography. For instance, Calderbank gives no heed to the numerical

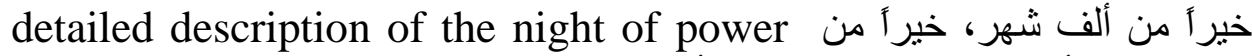
ثناثين ألف يوم، خير أ من ستين ألف نهار و ليل، خير أ من ثلاث و ثمانين سنة! He suffices with only stating it is better than "a thousand months" and transliterating it as "Laila Al-Quadr" without explaining its meaning in his footnotes. While Enani describes it more elaborately giving it a grand name "the night of power" .He does likewise in the tale of "I am a banner" relating the disconcerting incidence of the Prophet's death day, and the distressing impact even on the banner

ELLS Vol.9 No.I (345) SPU December 2018 
of Islam: وهزنى الفزع، و أنا أستمع إلى النبأ : Fear shook me when I heard the news (C)/ When I felt deeply perturbed, agitated, and my very mast shaken with terror, as the sad news reached my ears (E). In addition, Enani's hyperbolic language is quite ostensible in brusquely revealing the Prophet's gallantry and firm belief in God, by employing an overstated phrase like in: لم يهتز الرسول و لم يخف:The Prophet was not afraid (C)/ The Prophet wasn't in the least shaken, not a jot fear troubled him (E).

\subsubsection{Syntactic and Suprasegmental Features}

The two translators display different tackling for the syntactic structuring of the ST constructions. This can be detected in

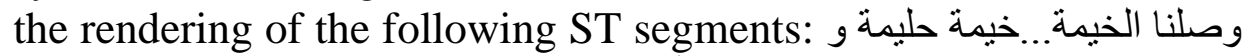
: الحارث. وصلنا.. و بدأ الخير الكثير يجىء إلينا. تغيرت الحال تمامأ : At last we reached the tent of Haleema and Al Harith. No sooner had we arrived than wonderful things began to happen to us (C)/ Back in the tent, the situation completely changed, with miraculous and unprecedented abundance! (E)

Obviously, Calderbank uses a rather paratactic technique in which he employs two separated sentences and he deleted the clause "تغيرت الحال تمامأ، Enani’s structure is hypotactic, however, with a rather complex syntactic organization. The ST clause "وصلنا الخيمة" is aptly transferred as a brief adverbial phrase "Back in the tent", and unlike Calderbank, he retains the deleted clause, setting it as the main clause, perhaps to show the sporadic situations after the presence of the blessed infant Muhammad. The independent ST clause "و بدأ الخير الكثير يجىء إلينا" is wrapped up in Calderbank's clause "wonderful things began to happen to us"; a clause which does not specify what kind of wonderful stuff takes place. While the same ST clause is well rendered by Enani in the complementary nominal group attributed with two adjectival groups "with miraculous and unprecedented abundance"; a structure which conveys to the TC readers that the presence of the blessed infant

\section{$\begin{array}{llllll}\text { ELLS Vol.9 No.I } & \text { (346) SPU December } 2018\end{array}$}




\section{Rania Abdel Baky Allam}

Muhammad is the impetus behind astounding, divine blessings and profusion never experienced before by Haleema and Al Harith.

In the example:أنا حجر وحيد...فريد...ليس لى مثيل: There are no other stones like me (C)/ I am unique-one of a kind, unparallel (E), Calderbank abides by the ST syntactic organization, suffices to translate the attributive clause "ليس لى مثنيل". He deletes the ST clause "أنا حجر وحيد...فريد" describing the holy Black Stone, maybe to be as brief as possible in the TT. Though, Enani attempts to produce a brief TT which conforms to the TL norms, yet he attempts to be as "ليس لى مثيل" concise and apposite as possible. The attributive clause is contracted dexterously into a negated attribute, adjectival group "unparallel".

Calderbank imitates the ST syntactic structure obviously in

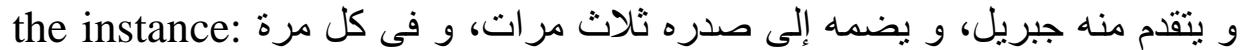
: يقول له: اقرأ. و يردد محمد فى كل مرة: مات ما أنا بقارى : So Jibreel went up to him and hugged him to his chest three times, each time saying to him: "Read! And each time Muhammad replied: "I cannot read" (C)/ Advancing, Gabreil hugged him and repeated the command and had the same answer, three times (E). Calderbank employs paratactic structure of coordinated, subsequent clauses. Besides, he transfers the dialogic part in the ST as a spoken dialogue in the TT. Enani's translational segment is also paratactic, yet more succinct and expressive, as the ST clause "و يتقدم منه جبريل "is reduced to a TT participial "Advancing". Moreover, he opts for transferring the dialogic part into concise coordinated phrases, which transfers the ST content.

The strategy of echoing the ST structure is repeated by Calderbank in many translational segments, while contracting strategy is adopted by Enani. This is apparent in the following instances: the clause“، حاولت السيدة خديجة أن تطمئن الرسول عليه الصلاة و "السلام is literarily transferred by Calderbank as: "Khadeeja tried to comfort the Prophet, praise and peace be upon him, saying". While Enani contracts it in a single adverbial group "Reassuringly, و كان الجدال مستمرَ بين الكفار و :Radija said". Similarly in the instance

\section{$\begin{array}{llllll}\text { ELLS } & \text { Vol.9 No.I } & \text { (347) } & \text { SPU } & \text { December } 2018\end{array}$}


بين الرسول: The Kuffar and the Prophet continued to argue (C)/ The argument raged unabated (E), Enani substituted the nominal head "الجدال" by one carrying the semantic load and he opts for a finite verbal group "raged" to intensify the frenzy, while the participial infinite adjectival attribute "unabated" carries the semantic meanings of continuity and fuming dispute.

As for the suprasegmental features, they are almost null in Calderbank's TT. While Enani resorts to using them in a few instances, like usage of brackets in: و صار على المشترى أن يدفع دنانير كثيرة في السلع التى كان يدفع فيها واحداً مثلى (Eor something worth a dinar, like me, people were made (to pay) two or three (E). The brackets may be added to emphasize the dire need and oppression suffered by the people in the year of poverty. In addition, he writes all the transliterated items in italics like: Ka'ba,'Iqra', Hijra, Qur'an, AlBur ${ }^{-} a q$, Beit Al-Maqdis and zaka etc. He uses italics sometimes for emphasis, like in the story "I am a Night", when the night of power speaks about its status "and am made a blessed night". Yet, he opts for either providing the TL equivalent for the item if available or explaining the transliterated word so as to render his TT reader friendly. This asserts that he targets young readers also. He even employs capitalization in items which he considers of a great significance and needs to be magnified like the oneness of God "the ONE God". Moreover, in all the translated verses of Quran Enani writes in a poetic stanza form to mark them. Such suprasegmental features elevates the tone of Enani's TT and make it more eligible for elder readers.

\subsubsection{Presupposition Features}

This parameter deals with what is not said in the TT- the items the translator assumes to be known by his TR. The present paper attempts also to show what is over said or added to the ST and in what order. Both translators have some presuppositions about the amount of information offered in their TTs, either by the addition of

\section{$\begin{array}{llllll}\text { ELLS Vol.9 No.I } & \text { (348) SPU December } 2018\end{array}$}


some segments or the deletion of others to fulfill a certain predetermined skopos.

The first group comprises examples in which each translator presupposes that his TRs need more elaboration, within the religious, historical or cultural fabric. Moreover, this addition may strengthen the meaning and brace the effect of the TT. This can be exhibited first in Calderbank's TT in nearly a single instance only, in which he added a rather theological imagery to describe the Prophet in a way closer to his TRs:ترتاح كلما نظرت إليه : An aura of peace and tranquility surrounds him (C).

On the contrary, the instances of addition are rather more notable in Enani's TT. They can be exhibited as follows: راحت حليمة : تبحث هناو هناك. و بعد وقت طويل عادت إلينا متعبة و حزينة Mecca, all came to grief. Halima had been away for a while looking here and there but came back in dismay and apparently more fatigue (E). The hypotactic structure adds to the distress of Haleema before finding the infant Muhammed to breast feed him. Later, the graces she was blessed by after breast feeding him are exhibited. The same meaning in the same contextual narrative is intensified by the added following segment by Enani: نجد- نحن الغنم و الناقة و أنا_العشب الذى يكفينا، و الماء الذى يروينا: An ideal grazing ground appeared for us all-the sheep, the she-camel and myself: there was enough grass to forage, enough water to drink (E).

In the instance, و لكنه حين عاد إليه الوحى، كان هذه المرة فى بيته : the next time a revelation came to him he was at home (C)/ But it was neither to the mountains nor to the cave that revelations came: it came at home! The surprise was too much (E). Calderbank follows the ST in a hypotactic structure. Enani adds a subordinate phrase maybe to render the segment more exciting to know where the second revelations came, and he intensifies it by closing the bracket of his TT segment by a clause that steps up the suspense and anticipation. The idea of adding flavors of narrative expectancy and excitement is repeated in instances like in the tale "I am a mountain" which relates the story of Uhud, Enani adds a whole

\section{ELLS Vol.9 No.I (349) SPU December 2018}


Comparing Two Translations of Abdel-Tawab Youssef's A Biography of Prophet

Mohammad Peace Be upon Him in Twenty Stories :A Skopos Functional Approach

clause serving as an alarm to the dismayed Muslim worriers to keep their stance and fight bravely: ارتفع صوت واحد من المسلمين: ماذا نصنع "What are we to do with life after Muhammad" A Muslim quickly asked. It was electrifying! (E)

In the tale entitled "I am a banner" the cultural and Islamic background of Enani as an ardent Muslim is apparent: فأيتهم عائدين إلى ، , When I saw them, later on, returning to Mecca as triumphant conquerors, raising high the banner of God's true religion (E). Enani, unlike Calderbank who translates "الدين"as "Islam", adds attributes to the nominal ST " "الدين" "God's true" to "religion". He assumes that not all of his TRs would consider Islam"God's true religion", so he adds the assumption as an incorporated part of the narrative.

Enani's background is apparent in his treatment of the segments that deal with the Jews. Maybe he wants to add some unsaid segments to Youssef's ST, however insinuated like in: صاحبتى يهودية: My owner is Jewish, far from being generous (E). This assumption is added from Enani's perspective, who feels no embarrassment to exhibit his opinions about Jews, even if some of his TRs maybe Jews themselves. This is elaborately revealed in the more detailed instance: و ز زاد من شدة الحال بهم، ما أقدم عليه يهود المدينة The hardship of the Muslims was made worse by the activity of the Jews in Al Madeenah (C)/ What exacerbated the situation the treachery of the Jews of Al-Madina. (E). The ST segment is rather implicit, inferring that the Jews took negative actions against Islam. Calderbank considers it mere "activity" and follows the same generalizing and implicit policy. While Enani makes the implicit apparent to convey his point of view about what the Jews did, which he considers frankly a "treachery".

In the following instances, Enani presupposes that his TL reader does not know about some Islamic cultural aspects. Thus he opts for adding some explanatory segments to elucidate such vagueness. For instance, in the tale "I am a tree" which relates the

\section{ELLS Vol.9 No.I (350) SPU December 2018}




\section{Rania Abdel Baky Allam}

story of Al Hudaybia peace treatment, some Muslims considered the tree blessed and went to visit it: و خاف عمر من كثرة زوَارى، فأمر أن U Umar was uneasy about the growing numbers fearing that the 'rite' would develop into cult. Enani explicates why Umar decided on cutting the tree radically, in fear that it may become a holy site as reverencing places other than the Kaa'ba is not a trait of the Islamic belief.

In the following instance, the whole scene of selling the merchandise by Uthman Ibn Affan in the tale "I am a dinar" is formally emblemised by Enani using, exegetic attributive phrases

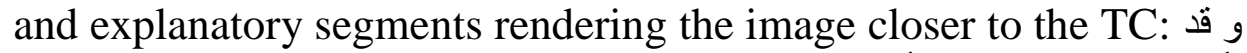
رأيت عثمان بن عفان، تأتيه تجارة من الثام فى فترة اشتندت فيها حاجة الناس إلى الطعام،

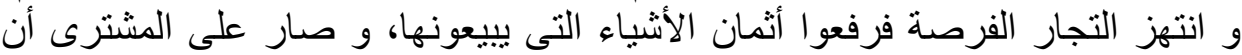

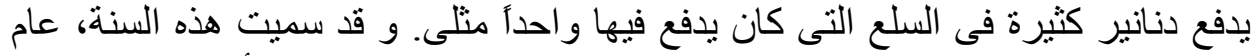
Uthman Ibn Afan', a rich man indeed, once stood out in the market with huge piles of merchandise just arrived from the Levant, I remember. The year had been an exceptionally lean one. There was an unprecedented drought, food was scarce and scarcity led to excessive price-rises, apart from the usual opportunities of some traders (E).

Once again, Enani employs his TT to convey the greatness of his religion by expounding segments rendering the cultural-bounded aspects clearer on the one hand and the narrative sequence more illuminating and informative on the other, like in the tale "I am a banner" in the scene relating the Prophet's death: فيقول عمر فكأنى لم أتل فئل هذه الآية قط : Though well known to many, the verse seemed to bring home the sense of shock which Umar Ibn Al-Khattab eloquently expressed. "It was as though I had never read that verse before!" (E). Enani adds logical segments which expound the sense of shock and sadness felt by Muslims. He elaborately does the same when he confirms the fact of the dire necessity of continuing the message of Islam even after the Prophet's death in the following instance: و طناد Everybody else was speechless, and the long, sad silence seemed endless. But then it had

\section{ELLS Vol.9 No.I (351) SPU December 2018}


Comparing Two Translations of Abdel-Tawab Youssef's A Biography of Prophet

Mohammad Peace Be upon Him in Twenty Stories :A Skopos Functional Approach

to be broken, as life must go on, and the noble vocation of the Prophet couldn't be interred with (E).

The second group comprises examples in which each translator presupposes that his TRs need not to know more details on a certain matter. Nonetheless, deletion in Calderbank's TT is more plentiful than Enani's, where deletion may be due to other reasons which the analysis attempts to explore. Calderbank's deletion strategy has an effect on his TT, as it may be considered incomplete in comparison to the elaborate rendering of Enani (which is even copious with extra details). This can be exhibited as follows: يوم بيوم بدر و الحرب سجال : This day makes up for what happened to us at Badr (C)/ This day is ours, in return for the Day at Badr! The fortunes of war alternate (E). Calderbank opts for not informing his TR readers about the nature of war fortunes. He states that it is a rancorous avenge from Quraysh's part to finish the Muslims off. Enani opts for adding the phrase which seems like a wise saying.

In the segment:لقد خسر المسلمون هذه المعركة على طريق النضال The Muslims had lost on the field of battle (C)/ The Muslims had lost the battle in the long war for the Truth (E), Calderbank opts for not transferring the idea that the Muslim's wars were honorable battles for attaining Truth and Justice. For him it is just "a field of battle". On the contrary, Enani is keen to convey that such wars were for deifying "the Truth".

In some instances of the book, Calderbank deletes a whole section. Nonetheless, in some instances deletion of a whole ST section comprising a very important feature of the Prophet's glorified traits is neither comprehensible nor justified. Contrarily, such exalted values and principles need to be adopted by younger generations. For instance, in the tale "I am a dinar", Calderbank deletes the story about the Prophet's rebuking his daughter Fatemah, for wearing a golden necklace, given to her as a gift. He shuns the idea of her wearing jewelry while poor Muslims may need it more

\section{ELLS Vol.9 No.I (352) SPU December 2018}


urgently. Deletion here for an integrated part intended to be conveyed by the ST producer is incompatible with Nord's (2005) principle of loyalty to the ST's intention.

Deletion in Enani's TT is decided on in a few instances, in which he weaves the content of the ST segments within the fabric of the translational segment. In other instances, he deletes some items to be substituted by other more comprehensive and inclusive ones. This can be elaborated as follows: و كان صلوات الله عليه قد نزل عليه عليه

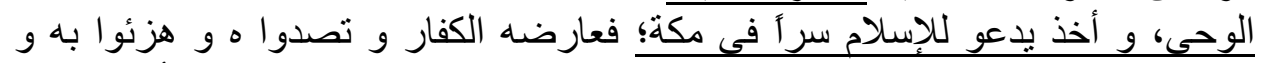
سخروا منه و آذوهو من اتبعوه أذى شديداً. It occurred to one of the men, as part of the unbelievers' campaign of abuse and ridicule, to exploit the incident in causing harm to Muhmmad (E).

\section{Findings and Conclusion}

It can be inferred from the previously conducted analysis that, Youssef's book A Biography of Prophet Mohammad Peace Be upon Him in Twenty Stories is mainly intended for young readers. Its main communicative function is referential referring to many objects, phenomena and characters in to inform the young readers about the great events that took place in the greatest Prophet's life. It has an expressive function, as Youssef's ST is quite prolific with expression about his profound love and reverence for the Prophet's exalted values, lofty principles, impervious morals and affectionate tenderness. Since the book exhibits literary ingenuity and rhetorical resourcefulness actualizing an entertaining function, enjoyable to juvenile readers (being related by animals, plants or objects), it thus achieves an appellative function. It supposedly induces younger generation to take the Prophet as a role model to emulate. Accordingly, to actualize Nord's (2005) principle of loyalty, the two TTs are supposed to maintain the same ST sender's intention and sustain the same functions assigned to the ST. However, through the analysis, it is proved that each translator adopts rather dissimilar

\section{ELLS Vol.9 No.I (353) SPU December 2018}


Comparing Two Translations of Abdel-Tawab Youssef's A Biography of Prophet

Mohammad Peace Be upon Him in Twenty Stories :A Skopos Functional Approach

translational strategies which result in attaining relatively desperate functions and conveying somehow divergent intentions.

Calderbank's intention is more or less to produce a marketoriented, commercially successful version, commemorating an award-winning best seller ST written for children. Therefore, in order to appeal to young readers he abides himself by the ST with a few instances of deviation. His lexical, metaphorical and organizational choices echo the ST to a great extent. He resorts to idiomatic manipulation in a very few instances, employing the same figures of speech even if they may seem alien to the TR. Simple, paratactic, linear constructions bonded mostly by coordinators suit young readers with limited reading capacities. It seems that, he wishes to convey the information in the simplest form, thus uses nearly no suprasegmental features, bearing in mind that the book may be read to young children by adults. Thus, inscription is less important than the vibrant graphics integrated in the conversational part. In Nord's (2018) terms, Calderbank generates a documentary type of translation. His TT replicates the ST, turning out to be a rather interlineal mirror text, with mainly referential communicative function, informing TL young readers about the life of the Prophet. Nevertheless, the strategy of inserting a footnote glossary disturbs the skopos of readiness to produce; a child-friendly book. Furthermore, he insists to abide by the ST in most of the TT, while deleting some SC aspects and peculiarities which need more elaboration. This makes the text informative rather than influential. The expressive function is not dominant, as he rarely adds lexical items that convey his feelings or appreciation to the Prophet or his doings, he even in some instances decides on sufficing with fewer attributives than the ST.

Although Calderbank relates the stories by its imaginative narrators, and he uses well-contrived expressions and a few TL oriented idioms, the literary, word-for-word documentary translation mars the enjoyable effect of the fables, and thus fails to

\section{ELLS Vol.9 No.I (354) SPU December 2018}


achieve the appellative function. However, the skopos of his TT is more or less marketable, most probably driven by the TI (the publishing house) to invest the profitable success of the ST. Nonetheless, such SL mirroring, documentary translation proves to be rather not ultimately valid in producing a children book with the same literary creativity and linguistic enjoyable contrivance as the original.

Enani's intention is to produce a TL version of a book glorifying mainly Youssef's rhetorical style which exhibits the aptitude of Arabic as a language that can achieve aesthetic quality, nifty presentation and scrupulous historical and religious credentials. Enani intends to translate the book so as to fit both adults as well as younger readers (whether Muslims or not). However, he adopts well schemed translational strategies which make the produced TT more suitable for elder, more mature readers. This can be justified as a means of elevating young readers' linguistic competence and reading capabilities. In spite of not lacking excitement, creativity and narrative flavours, his TT needs profound reading and knowledge of elevated diction and expressions. It is TL oriented and seems as if originally written in advanced English. His syntactic structures are rather hypotactic, with rather complex, main-subordinate structures, substituting long explanatory phrases and sometimes clauses by shorter adjectival and adverbial attributive groups, giving a TL hue to his grammatical fabric. He employs some suprasegmental features, bearing in mind that the book is going to be read and he wants to assert a certain tonal significance to certain parts in the TT. Enani's TT is thus highly instrumental, in Nord's (2018) terms. His ardent Islamic and Arabic background, linguistic manipulations, idiomatic expressions, metaphorical renderings, lofty lexical diction and complex syntactic structures bring the SC home to the TR. His intention is to let the Islamic, Arabic SC as comprehensible and explicable as possible for the English speaking reader. Consequently, his heady linguistic competence entails an addition; manipulative translational strategy

\section{ELLS VoI.9 No.I (355) SPU December 2018}


aptly clarifying aspects of the SC and glorifying Islamic principles exemplified in the Prophet's being, and thus achieves a referential communicative function. Moreover, the added ST segments actualize a dominant expressive function, conveying the translator's feelings, adulation, and reverence for Prophet's Muhammad. The highly rhetorical and literary presentation adds an appellative function for the readers to take the same line of thought and action, attaining loyalty to the intention and functions of the ST. The skopos of Enani's TT is to offer a presentable, emblematic TL oriented text, acceptable in the TC, informative about the SC, comprehensible to the TR and in conformity with literary creative and linguistically of the original.

As for the parameters of Nord's (2005, 2018) model, although applied in a bottom-up manner they prove to be quite functional in realizing the broader milieu of the ST and construing the predetermined communicative functions and skopoi of the two TTs. They highlight the specificity of the ST subject matter and genre as well the TT recipients. Furthermore, the detailed, meticulous interatextual factors exhibit that Calderbank's TT is more loyal to the ST functions, intentions and content in most of its part, but not adequate to the TC. Enani's TT is both loyal to the ST functions, intentions and content and adequate with respect to the TL and the TC at the same time. All this is comprehended without an explicit TB.

Eventually it can be inferred that, the functions and skopoi of the two TTs are rather dissimilar; Calderbank's TT skopos is congruent to empower the hit of an amusing children best seller, while Enani's TT skopos is to create a mediating channel between the TR and the SC, in cross cultural translational communicative action. However, the closest translation product to the ST is that of Enani being loyal, adequate and above all enjoyable.

\section{ELLS VoI.9 No.I (356) SPU December 2018}




\section{Recommendation}

The present study has certain limitations of scope, comparing mainly two TTs. Accordingly, it is recommended for future researches that, Nord's $(2005,2018)$ model of translation can be readily applied to the analysis of a group of TTs, perhaps conducting a quantitative empirical analysis that may yield reliable results about different translational strategies.

Furthermore, many researches that employ the functional, translational action approach apply it on non-literary STs. Future researches may be directed to applying such approach on different literary, historical, religious and even classical works. For, it has proved according to this research to be valid for the analysis of different ST genres, and for the conducting studies of a comparative nature.

\section{$\begin{array}{llllll}\text { ELLS VoI.9 } & \text { No.I (357) SPU December } 2018\end{array}$}


Comparing Two Translations of Abdel-Tawab Youssef's A Biography of Prophet

Mohammad Peace Be upon Him in Twenty Stories :A Skopos Functional Approach

\section{References}

Al Khamiri, S.H. (2015). Translating Emirati Folklore (Master's thesis). American University of Sharjah, United Arab Emirates. Retrieved from: https://dspace.aus.edu/.../29.2322015.13\%20Shaikha\%20H.\%20Al\%20Khamiri.pdf?

Alsabbagh, A. (2014). Skopos for children's literature: Translation and commentary (Master's thesis). American University of Sharjah, United Arab Emirates. Retrieved from: https://dspace.aus.edu/.../29.232-2014.03\%20\%20Aliaa\%20Alsabb.

Bouziane, K. (2016). "Skopos theory in the translation of online advertising from English into Arabic". Professional Communication and Translation Studies, 9, 139-146. Retrieved from:

https://www.google.com/url?sa=t\&rct=j\&q=\&esrc=s\&source=we b\&cd=1\&ved=2ahUKEwjSj5mr-eAhUL2xoKHabRCjEQFjAAegQIBhAC\&url=https\%3A\%2F\% 2Fsc.upt.ro\%2Fimages\%2Fcwattachments\%2F121_3a146f467539 21fe350a5ee8e8418c6a.pdf\&usg=AOvVaw2HY_tuG_HbEIdHMW0NL3c

Calderbank, T. (2010). The life of Muhammad may the blessing and peace of God be upon him in twenty stories. Cairo: Dar El Shorouk.

Calvo, E. (2018). "From translation briefs to quality standards: Functionalist theories in today's translation processes". The International Journal for Translation \& Interpreting Research. 10(1), 18-32. DOI:10.12807/ti.110201.2018.a02

Coillie, J.V. (2006). Characters names in translation: A functional approach. In J. V. Collie and W. P. Verschueren (Eds.), Children's literature in translation: Challenges and strategies (pp. 123-139). Manchester: St Jerome.

Dickins, J., Hervey, S., \& Higgins, I. (2002). Thinking Arabic translation, a course in translation method: Arabic to English. Abingdon: Routledge.

Enani, M. (2017a). A life of the prophet Muhammad in twenty tales. In L. A. Youssef (Ed.), For the Love of Abdel-Tawab Youssef: Essays in Language and Literature in Honour of Abdel-Tawab Youssef (pp.

ELLS Vol.9 No.I (358) SPU December 2018




\section{Rania Abdel Baky Allam}

39-91). Cairo: Centre for Languages and Professional Translation Cairo University.

Enani, M. (2017b). Abdel-Tawab Youssef: A personal note. In L. A. Youssef (Ed.), For the Love of Abdel-Tawab Youssef: Essays in Language and Literature in Honour of Abdel-Tawab Youssef (pp. 29-38). Cairo: Centre for Languages and Professional Translation Cairo University.

Hanninen, R. (2006). Translating magazine articles: Two analyses. (Pro gradu thesis). University of Tampere. Retrieved from: https://www.google.com/url?sa=t\&rct=j\&q=\&esrc=s\&source=we b\&cd=1\&ved=2ahUKEwjNgNabj_DeAhUDzhoKHVE0AG0QFj AAegQIABAC\&url=https\%3A\%2F\%2Ftampub.uta.fi\%2Fbitstrea $\mathrm{m} \% 2$ Fhandle\%2F10024\%2F94017\%2Fgradu01463.pdf\&usg=AO vVaw0M1viF7LzGeu_-kqKihdkF

Kalliomäki, H. (2007). Translating fictitious science: A case study of the translation process of two short stories by Issac Asimov. (Pro gradu thesis). University of Jyvaskyla. Retrieved from: https://jyx.jyu.fi/dspace/bitstream/handle/.../7420/URN_NBN_fi_j yu-2007617.pdf?

Khalifa, O. (2017). A reading of two translations of Abdel-Tawab Youssef's Hayat Muhammad Fi 'Ashrine Quessa: A cultural perspective. In L. A. Youssef (Ed.), For the Love of Abdel-Tawab Youssef: Essays in Language and Literature in Honour of AbdelTawab Youssef (pp.93-106). Cairo, Centre for Languages and Professional Translation Cairo University.

Nord, C. (1995). "Text-functions in translation: Titles and headings as a case in point". Target, 7(2), 261-284. Retrieved from: https://www.academia.edu/12701579/Text

Nord, C. (1997a). "Defining translation functions: The translation brief as a guideline for the trainee translator". Ilha do Desterro, (33), 4455.

Retrieved

from:

https://periodicos.ufsc.br/index.php/desterro/article/view/9208/948 4doi:https://doi.org/10.5007/\%x.

Nord, C. (1997b). A Functional typology of translations. In A. Trosberg (Ed.), Text typology and translation (pp.43-66). Amsterdam: John Benjamins Publishing Company.

\section{ELLS Vol.9 No.I (359) SPU December 2018}


Comparing Two Translations of Abdel-Tawab Youssef's A Biography of Prophet

Mohammad Peace Be upon Him in Twenty Stories :A Skopos Functional Approach

Nord, C. (2005). Text analysis in translation: Theory, methodology, and didactic application of a model for translation-oriented text analysis. Amsterdam: Rodopi B.V.

Nord, C. (2006a). "Translating as a purposeful activity: a prospective approach". TEFLIN, 17(2), 131-143. Retrieved from: teflin.org/journal/index.php/journal/article/viewFile/65/254

Nord, C. (2006b). "Loyalty and fidelity in specialized translation". Confluencias-Revista de Tradução Científica e Técnica, (4), 2941.

Retrieved from: web.letras.up.pt/egalvao/TTCIP_Nord\%20loyatly\%20and\%20fide lity.pdf

Nord, C. (2016). "Bible translation: Function + loyalty: Theology meets skopos". Open Theology, (2), 566-580. DOI 10.1515/opth-20160045

Nord, C. (2018). Translating as a purposeful activity: Functionalist approaches explained. Oxon: Routledge.

Ramos, F. P. (2002). "Beyond the confines of literality: A functionalist approach to the sworn translation of legal documents". Puentes, (2), 27-33. Retrieved from: wpd.ugr.es/ greti/revistapuentes/pub2/04-articulo.pdf

Reiß, K. and Vermeer \& H.J.(2014). Towards a General Theory of Translational Action: Skopos Theory Explained. (C. Nord, Trans.).London: Routledge.

Sami, K. (2017). Far from the maddening crowd: Abdel-Tawab Youssef's narrative creed. In L. A. Youssef (Ed.), For the Love of AbdelTawab Youssef: Essays in Language and Literature in Honour of Abdel-Tawab Youssef (pp. 131-148). Cairo: Centre for Languages and Professional Translation Cairo University.

Sas, I. (2010). The treacle triplets: A functional approach to the translation of children's literature (Master's thesis). Stellenbosch University. Retrieved from:scholar.sun.ac.za/handle/10019.1/5344 Serban, A. (2006). "Translation and genre: Sacred texts". In Encyclopedia of language and linguistics, vol. 12 ( pp. 47-53). Boston: Elsevier Ltd.

Youssef, A. (2008). حياة محد صلى الهه عليه و سلم فى عشرين قصة. Cairo: Dar El Shorouk.

\section{$\begin{array}{llllll}\text { ELLS Vol.9 No.I } & \text { (360) SPU December } 2018\end{array}$}

